\title{
Progesterone vaginal ring: Safe for mothers and babies
}

Population Council

Follow this and additional works at: https://knowledgecommons.popcouncil.org/departments_sbsr-rh

Part of the Demography, Population, and Ecology Commons, Family, Life Course, and Society

Commons, International Public Health Commons, Maternal and Child Health Commons, and the Women's Health Commons

How does access to this work benefit you? Let us know!

\section{Recommended Citation}

"Progesterone vaginal ring: Safe for mothers and babies," fact sheet. New York: Population Council, 2015. 


\section{PROGESTERONE VAGINAL RING SAFE FOR MOTHERS AND BABIES}

\section{The Progesterone Vaginal Ring (PVR) is a vaginal ring which contains progesterone and can prevent pregnancy. It has been proven to be a safe and effective method of contraception for lactating women.}

The PVR is safe for mothers and their infants because it relies on the mother breastfeeding and there are no effects on health. It works as a contraceptive by:

- Reinforcing the inhibitory effect of breastfeeding on ovulation.

- Extending postpartum amenorrhea.

\section{PVR DOES NOT AFFECT BREASTFEEDING}

A nursing mother will be able to breastfeed without disruption. She will be able to nurse just as much and for as long as she would have without the PVR. The natural hormone progesterone that is in the ring does not affect the volume of breast milk a lactating woman produces or the frequency of breastfeeding (Nath and Sitruk-Ware 2010). On the contrary, the efficacy of the method depends on continued breastfeeding with a minimum of four feeding episodes per day.

A clinical trial comparing the PVR and the IUD found that women on the PVR breastfed for the same amount of time or longer than those on the IUD. Reasons for weaning were similar in both groups (Sivin et al. 1997).

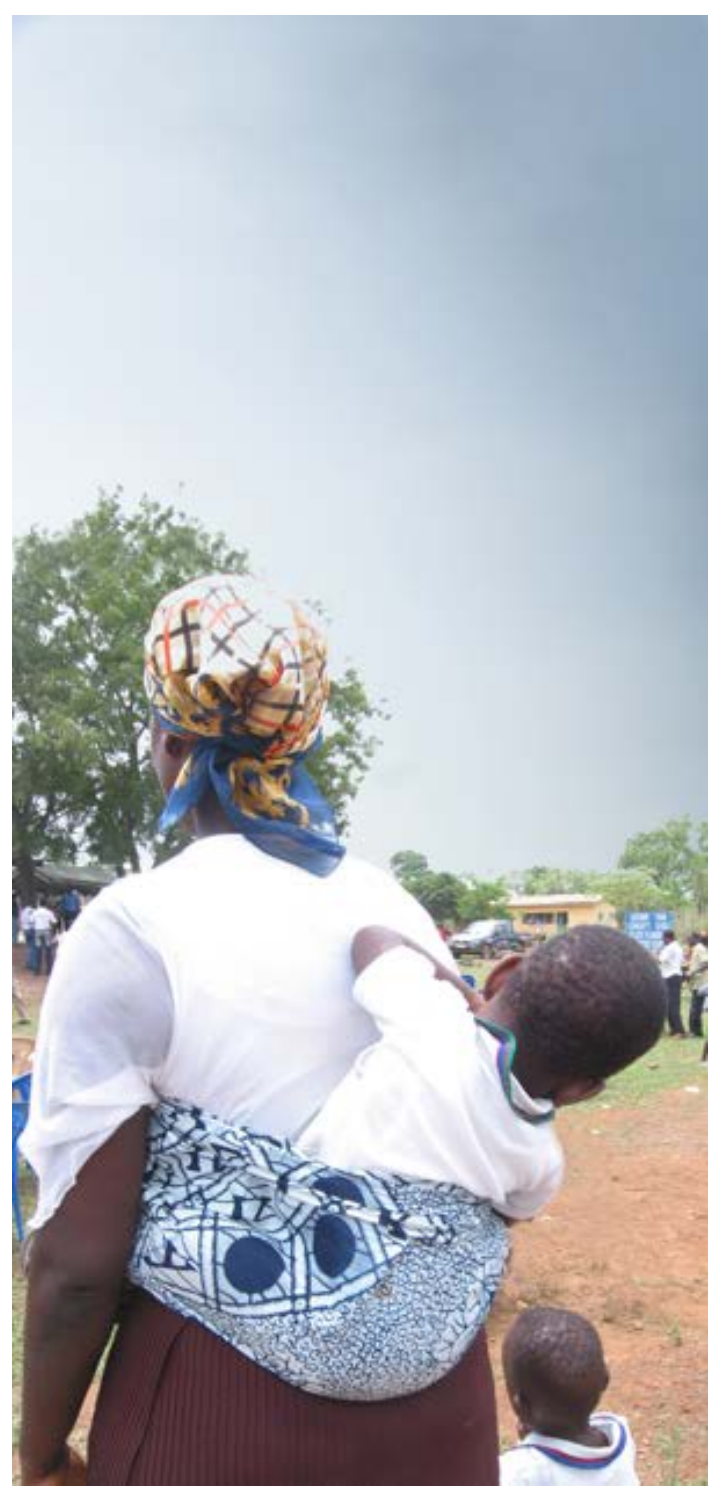




\section{EFFECT ON INFANT HEALTH}

The PVR has been shown to have no effects on the growth or development of infants whose mothers were using it.

Clinical trials have demonstrated that infants of mothers who were using the PVR did not differ in growth and development than those whose mothers were using the copper IUD (Nath and Sitruk-Ware 2010).

- The weights of infants of mothers using the PVR were similar to those of whose mothers were using the IUD over the first year of life. Similar infant weight increases over the first year of life have been reported by other clinical studies as well (Massai et al. 2005).

- The dose of the hormone delivered by the ring is lower than what an ovulating woman would normally secrete in her blood. Therefore, the exposure an infant has to the hormone is far lower than what it would be if its mother had resumed her regular menstrual cycles.

- When mothers use contraception, babies typically get very low levels of progesterone from breast milk. For example, estimates indicate that babies of mothers using implants receive about 5 $\mathrm{mcg} /$ day of progesterone which is considerably lower than the European Medicines Agency (EMA) stipulated maximum intake of $150 \mathrm{mcg}$ per day.

- Less than 10 percent of progesterone is bioavailable to babies due to the low levels of progesterone in breast milk and its short half-life after passing through the baby's digestive tract where the hormone is quickly eliminated (Nath and Sitruk-Ware 2010; Massai et al. 2000).

\section{EFFECT ON SEXUAL PARTNERS}

Sexual partners have limited exposure to the progesterone in the ring and hence are not affected by it. At most, some men may feel the presence of the ring. Users have reported that the ring has not had any effect on their or their partner's sexual pleasure (Nath and Sitruk-Ware 2010).

\section{EXPANDING CONTRACEPTIVE OPTIONS}

In 2015, the PVR has been added to the World Health Organization's (WHO) Essential Medicines List (EML) and Medical Eligibility Criteria (MEC) for Contraceptive Use guidance for providers.

\section{SUMMARY}

The PVR is an effective and safe contraceptive for mothers, their babies, and their sexual partners. This method vastly expands the range of contraceptive choices available for nursing women.

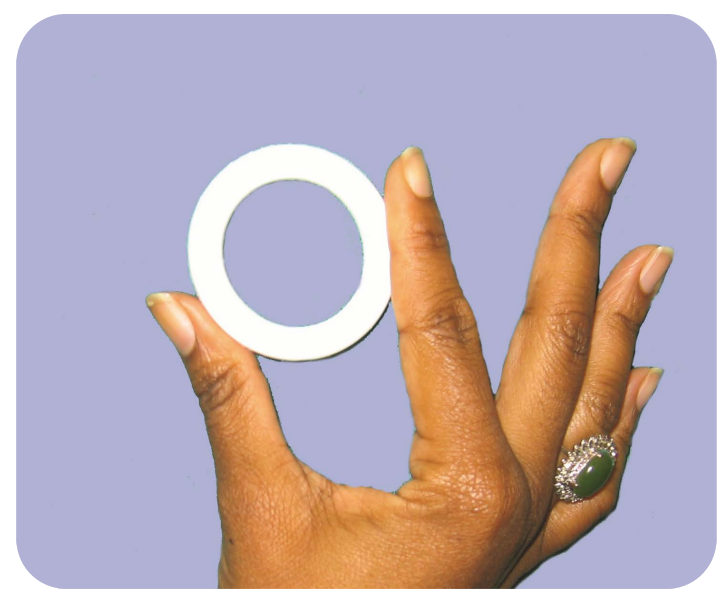

\section{References}

Massai, Rebeca, Soledad Diaz, Ted Jackanicz, and Horacio B. Croxatto. 2000. "Vaginal rings for contraception in lactating women" Steroids 65: 703-707.

Massai, Rebeca, Eliana Quinteros, María Verónica Reyes, Roxana Caviedes, Ana Zepeda, Juan Carlos Montero and Horacio B. Croxatto. 2005.

"Extended use of a progesterone-releasing vaginal ring in nursing women: a phase II clinical trial" Contraception 72: 352-357.

Nath, Anita and Regine Sitruk-Ware. 2010. "Progesterone vaginal ring for contraceptive use during lactation" Contraception 82: 428-434.

Sivin, Irving, Soledad Díaz, Horacio B. Croxatto, et al. 1997.

"Contraceptives for lactating women: A comparative trial of a progesteronereleasing vaginal ring and the Copper T 380A IUD" Contraception 55: 225232.

Truitt, S.T., A.B. Fraser, Maria F. Gallo, L.M. Lopez, D.A. Grimes, and K.F. Schulz. 2003. "Combined hormonal versus nonhormonal versus progestinonly contraception in lactation" Cochrane Database of Systematic Reviews, Issue 2, Art. No.: CD003988. DOI: 10.1002/14651858.CD003988.

\section{CONTACT INFORMATION}

For more information about the Council, please refer to our website at www.popcouncil.org 